\title{
Effect of air and fuel supercharging on emissions from an agricultural engine
}

\section{Efeito da sobrealimentação de ar e combustível nas emissões de um motor agrícola}

\author{
Marcelo Silveira de FARIAS ${ }^{1}$; José Fernando SCHLOSSER ${ }^{2}$; Gilvan Moisés BERTOLLO³; \\ Giácomo Müller NEGRI ${ }^{4}$; Luis Fernando Vargas de OLIVEIRA ${ }^{5}$
}

${ }^{1}$ Autor para correspondência. Doutor em Engenharia Agrícola. Universidade Federal de Santa Maria, Campus de Frederico Westphalen, Departamento de Ciências Agronômicas e Ambientais. Linha 7 de Setembro, s/n, BR 386 km 40 , CEP: $98400-000$, Frederico Westphalen, RS. silveira_farias@hotmail.com

${ }^{2}$ Doutor em Engenharia Agrícola. Universidade Federal de Santa Maria. josefernandoschlosser@gmail.com

${ }^{3}$ Doutor em Engenharia Agrícola. Universidade Regional do Noroeste do Estado do RS. gilvanbertollo@yahoo.com.br

${ }^{4}$ Aluno do curso de Agronomia. Universidade Federal de Santa Maria. gm.negri14@gmail.com

${ }^{5}$ Aluno do curso de Engenharia Mecânica. Universidade Federal de Santa Maria. fernando.mec.ufsm@gmail.com

Recebido em: 06-02-2018; Aceito em: 22-05-2018

\begin{abstract}
Pollutant gases emitted by engines depend mainly on the applied load and engine speed. This study quantifies the emissions of pollutant gases from a diesel-cycle engine, while changing the configuration of the air and fuel supply system. We analyzed the variables particulate matter $\left(\mathrm{g} \mathrm{kWh}^{-1}\right)$, carbon monoxide $\left(\mathrm{g} \mathrm{kWh}^{-1}\right)$, nitrogen oxides $\left(\mathrm{g} \mathrm{kWh}{ }^{-1}\right)$, oxygen (\%vol.) and hydrocarbons $\left(\mathrm{g} \mathrm{kWh}^{-1}\right)$, in different engine configurations (aspirated; aspirated + service; turbocharged + service; and turbocharged). Dynamometric experiments were carried out by means of the power take-off of an agricultural tractor. The experimental design was completely randomized, in a two-factorial scheme with three replicates. The results indicate that engine supercharging, compared to the original configuration, significantly reduces the particulate matter of gases and carbon monoxide, but increases the levels of nitrogen oxides emitted. The load applied to the engine was directly related to the emissions, except for oxygen.
\end{abstract}

Additional Keywords: agricultural tractor; greenhouse gases; injection pump; turbocharger.

\section{Resumo}

Os gases poluentes emitidos pelo motor dependem, principalmente, da carga aplicada e de sua rotação de trabalho. Objetivou-se quantificar as emissões de gases poluentes de um motor ciclo Diesel, alterando a configuração do sistema de alimentação de ar e de combustível. As variáveis analisadas foram material particulado $\left(\mathrm{g} \mathrm{kWh}^{-1}\right)$, monóxido de carbono $\left(\mathrm{g} \mathrm{kWh}^{-1}\right)$, óxidos de nitrogênio $\left(\mathrm{g} \mathrm{kWh}^{-1}\right)$, oxigênio (\% vol.) e hidrocarbonetos $\left(\mathrm{g} \mathrm{kWh}^{-1}\right)$ em diferentes configurações do motor (aspirado, aspirado + serviço, turboalimentado + serviço e turboalimentado). Foram realizados experimentos dinamométricos por meio da tomada de potência de um trator agrícola. O delineamento experimental utilizado foi o inteiramente casualizado, em esquema bifatorial, com três repetições. Os resultados indicam que a sobrealimentação do motor, em relação à configuração original, proporciona redução significativa de material particulado dos gases e do monóxido de carbono, porém aumento dos níveis de óxidos de nitrogênio emitidos. A carga aplicada ao motor esteve diretamente relacionada às emissões, exceto para oxigênio.

Palavras-chave adicionais: bomba injetora; gases de efeito estufa; trator agrícola; turbocompressor.

\section{Introduction}

The growing environmental concern constrains the use of fossil fuels, which are the main responsible for the emission of pollutant gases in the atmosphere (Frantz et al., 2014). Global energy consumption and the adverse environmental effects of its use have had significant increases in the past century and are projected to continue to increase in the future (Janulevicius et al., 2013; Lebedevas et al., 2013).

The main imbalance resulting from the burning of fuels occurs in the carbon cycle $\left(\mathrm{CO}\right.$ and $\left.\mathrm{CO}_{2}\right)$, which, in high amounts in the environment, contributes to global warming (Giakoumis et al., 2013). Nitrogen oxides (NOx) and particulate matter, emitted after combustion, contribute to the formation of acid rain and to the destruction of the ozone layer (Amoroso et al., 2006). These emissions cause problems for human health, and their long-term effects are related to diseases with cancer risk (Tadano et al., 2014). Moreover, short-term effects include respiratory problems, eye irritation and cough (Hosseinpoor et al., 2005).

The agricultural tractor is the most used ma- 
chine in the rural environment. There is an estimation of twenty-nine million tractors equipped with dieselcycle engines in the world (Bilski, 2013); given the efficiency and reliability of such engines (Perin et al., 2015). Currently, manufacturers of these engines for the agricultural sector often use turbocharger to achieve higher horsepower. According to Farias (2014), in the Brazilian market, this tendency is observed in engines with nominal power above $55 \mathrm{~kW}$.

Air supercharging using a turbocharger centrifugal compressor allows to use the energy of the exhaust gases to move a turbine, installed in the engine air intake system. Therefore, a greater amount of air enters the cylinder (Karabektas, 2009).

For aspirated engines, specialized companies provide sets for the supercharging of air, which are installed in engines of new and used tractors at the request of consumers. Such practice increases the availability of power by the engine at low cost, which results in a cost-effective solution. This process introduces in the cylinder a volume of air greater than the one corresponding to natural aspiration. Thus, even with the same cylinder capacity, a greater power is achieved (Giacosa, 1980; Márquez, 2012).

To obtain significant gains in engine power, besides adding the kit, an increased volume of fuel must be injected into the cylinder (Karabektas, 2009). These different configurations in the air and fuel supply system are known to engine manufacturers and are often used to produce a lot of engines meeting a wide range of power from a single engine block design (Márquez, 2012).

Despite the abundance of studies assessing the emissions from vehicle engines, diesel-cycle engines are still little researched. In this sense, the present work quantifies the emissions of pollutant gases from a diesel-cycle engine of an agricultural tractor, while changing the configuration of the air and fuel supply system.

\section{Material and methods}

The experiment was conducted under laboratory conditions in the Agricultural Machinery Test Center, at the Federal University of Santa Maria in Santa Maria city, Rio Grande do Sul State, Brazil, (29ำ 43' 21.3" S; 53ํ 43' 08.0" W; 102 m). A Massey Ferguson tractor, model MF 4275, was used. The tractor was equipped with a four-stroke diesel-cycle engine with 32 hours of use, Perkins brand, model 1104A-44, with four cylinders, total cylinder capacity of $4,400 \mathrm{~cm}^{3}$ and natural aspiration. According to the manufacturer, the maximum engine torque and power are $275 \mathrm{Nm}$ and $56 \mathrm{~kW}$ (75 hp), respectively, following the ISO TR 14396 standard. The fuel supply system comprised a rotary-type mechanical injection pump, Delphi brand, model 1463. The diesel fuel used in the experiment was purchased from the local automotive supply network, with a specific mass of $0.875 \mathrm{~kg} \mathrm{~L}^{-1}$ at $18.5^{\circ} \mathrm{C}$.
A two-factor scheme was used, evaluating the following factors: air and fuel supply system configuration (C1; C2; C3; and C4) and engine speeds $(1,300$, $1,400,1,500,1,600,1,700,1,800,1,900,2,000$ and $2,100 \mathrm{rpm})$, in a completely randomized experimental design with three replicates.

The engine was altered to establish the air and fuel supply system configuration factor. Initially, we evaluated the tractor engine in its original configuration (C1: Aspirated). Subsequently, the injection pump was set up on a test bench, where the fuel flow or load of this device went from $67 \mathrm{ml}$, at $800 \mathrm{rpm}$ of the injection pump, to $74 \mathrm{ml}$. Thus, the device had a $10 \%$ increase in the injected fuel, which determined the second configuration (C2: Aspirated + Service). To evaluate the effects of the turbocharger on engine performance, a kit for air supercharging, Master Power brand, model APL 240 was installed. The device has an air intake pressure of 1.0 bar, being set after the service performed in the injection pump (C3: Turbocharged + Service). With the turbocharger installed, for the last evaluated configuration, the original injection pump flow was used again (C4: Turbocharged).

Prior to the experiment, using the torque brake to reach the optimum operating temperature, the engine was warmed up, imposing a sufficient load to reduce its maximum speed (2,350 rpm) by $25 \%$ for a period of 20 minutes. The torque brake was set to brake at each 100 rpm decrease in engine speed from the first data collected from 2,100 to $1,300 \mathrm{rpm}$, where the maximum power and maximum torque speeds were found, respectively, to all configurations evaluated. The collection time of exhaust gases and particulate matter at each engine speed was two minutes, with the first third of the data being discarded to stabilize the measuring equipment. Data were collected every two seconds with 40 observations for each configuration and for each engine speed, totaling 1,440 observations.

A gas analyzer, SAXON brand, model Infralyt ELD was used to measure the main engine exhaust gases, carbon monoxide (CO) (\%vol.), nitrogen oxides (NOx) (ppm), oxygen $\left(\mathrm{O}_{2}\right)$ (\%vol.) and hydrocarbons (HC) (ppm). The particulate matter (PM) present in the exhaust gases was measured by means of the light absorption coefficient ( $k$ value), using the SAXON opacimeter, model Opacilyt 1030. The control and acquisition of the data measured by these two devices was achieved through the computer program MW IELD 01030. In addition, gas temperature $\left({ }^{\circ} \mathrm{C}\right)$ values were collected using a type $\mathrm{k}$ thermocouple. To transform the unit to $\mathrm{g} \mathrm{kWh}^{-1}$, the equations presented by Pilusa et al. (2012) were used.

To obtain the exhaust gases and PM values as a function of the engine speed through the tractor's power take-off (PTO), an electric torque brake, EGGERS brand, model PT 301 MES was used, with braking capacity up to $551 \mathrm{~kW}(750 \mathrm{hp})$. The engine braking intensity was assessed using EGGERS Power Control software, which manages the use of the dynamometer. 
The Opacilyt used in this research presents partial flow, and the graduated chamber has a length of $430 \mathrm{~mm}$. The PM is measured by a beam of light emitted perpendicularly to the direction of the exhaust gases. The difference in intensity between the emitted light and the received light after passing through the exhaust gases determines the number of particles in the gases. Due to the formation of water vapor, expelled through the engine exhaust pipe, this equipment was fixed in a tower with height greater than the exhaust pipe, so as not to damage the equipment and not to compromise the PM measurement. Infralyt has a water condenser, so it does not need to be fixed on the exhaust pipe. With both devices connected via software and computer, the collection of PM and gaseous emissions took place at the same time by means of a metal probe installed inside the engine exhaust pipe. The schematic representation of the experiment is shown in Figure 1.

In the statistical analysis, the data were analyzed for their normality and homoscedasticity. After collection, all variables were submitted to analysis of variance ( $p \leq 0.05)$. In the case of significance, means were analyzed by Tukey's test ( $p \leq 0.05)$.

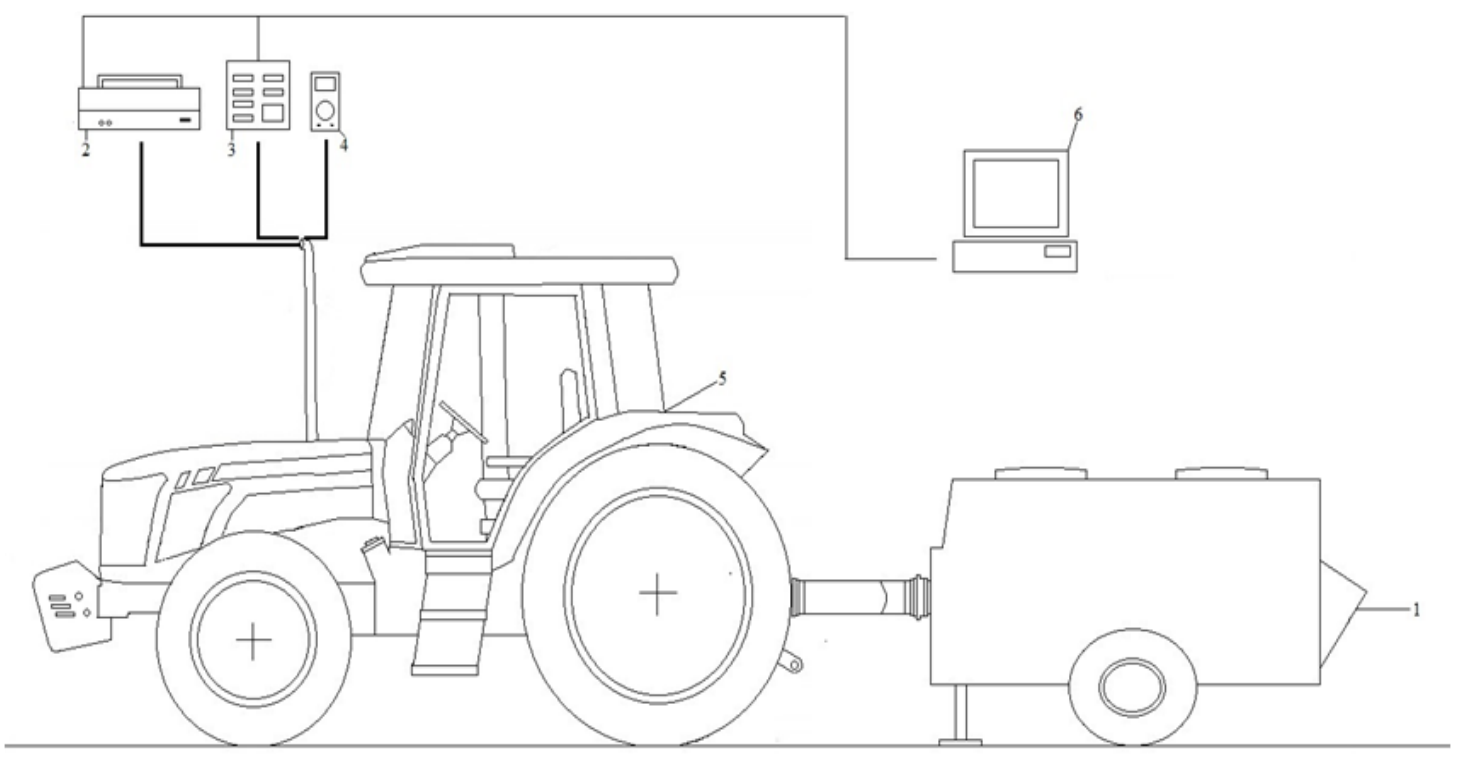

Figure 1 - Diagram of the experiment (1. dynamometer brake, 2. opacimeter, 3. gas analyzer, 4. type $\mathrm{k}$ thermocouple, 5. agricultural engine, 6. MW IELD 01030 software).

\section{Results and discussion}

The analysis of variance of the results for particulate matter and pollutant gases emissions $\left(\mathrm{CO}, \mathrm{NO}_{\mathrm{x}}\right.$, $\mathrm{O}_{2}$ and $\mathrm{HC}$ ) in the four configurations of the air and fuel supply system evaluated (Factor $A$ ) and in the different engine speeds (Factor $B$ ) showed that the all variables presented variation (Table 1), whose equations are described in Table 2.

Emissions decrease with the reduction of the load applied to the engine (Figure 2a, 2b, 2c and 2e), i.e., in the highest speeds, in which the torque values are generally smaller, corroborating the results obtained by Perin et al. (2015). Furthermore, the results indicate that only with the increase of injected fuel (C2: Aspirated + Service), the $\mathrm{CO}$ and $\mathrm{HC}$ emissions were higher than the original configuration (C1: Aspirated). Rich mixture, i.e., greater amount of fuel relative to the number of $\mathrm{O}_{2}$ molecules, not having a stoichiometric equilibrium, as well as the non-uniform mixing thereof within the cylinder, may favor the formation of carbon monoxide and hydrocarbons.

Table 1 - Analysis of variance for the assessed parameters: particulate matter (PM); carbon monoxide (CO); nitrogen oxides $\left(\mathrm{NO}_{\mathrm{x}}\right)$; oxygen $\left(\mathrm{O}_{2}\right)$ and hydrocarbons $(\mathrm{HC})$.

\begin{tabular}{|c|c|c|c|c|c|c|}
\hline \multirow{2}{*}{$\begin{array}{l}\text { Sources of } \\
\text { variation }\end{array}$} & \multirow{2}{*}{$\begin{array}{l}\text { Degrees of } \\
\text { freedom }\end{array}$} & \multicolumn{5}{|c|}{ Mean squares } \\
\hline & & PM & $\mathrm{CO}$ & $\mathrm{NO}_{\mathrm{x}}$ & $\mathrm{O}_{2}$ & $\mathrm{HC}$ \\
\hline Factor A & 3 & 11.99 & 154.41 & 22.42 & 178.28 & 0.01 \\
\hline Factor B & 8 & 1.44 & 13.16 & 80.83 & 26.20 & 0.00 \\
\hline$A \times B^{*}$ & 24 & 0.31 & 11.75 & 2.19 & 0.79 & 0.00 \\
\hline Residue & 72 & 0.06 & 0.03 & 0.02 & 1.08 & 0.00 \\
\hline$F_{c}(A \times B)$ & & 26.85 & $1,063.92$ & 157.13 & 5.42 & 157.52 \\
\hline CV (\%) & & 14.29 & 6.03 & 1.40 & 4.73 & 2.22 \\
\hline
\end{tabular}

${ }^{*}$ Significant by the $\mathrm{F}$ test $(\rho \leq 0.05) .{ }^{* *}$ Calculated $\mathrm{F}(\mathrm{Fc})$; Coefficient of variation $(\mathrm{CV})$. 
Table 2 - Regression equations and respective adjusted $\mathrm{R}^{2}$ for particulate matter (PM) and emissions for carbon monoxide $(\mathrm{CO})$, nitrogen oxides $\left(\mathrm{NO}_{\mathrm{x}}\right)$, oxygen $\left(\mathrm{O}_{2}\right)$ and hydrocarbons $(\mathrm{HC})$ for Aspirated $(\mathrm{C} 1)$, Aspirated + + Service (C2), Turbocharged + Service (C3) and Turbocharged (C4) settings.

\begin{tabular}{|c|c|c|c|c|}
\hline Gases & C1 & $\mathrm{C} 2$ & C3 & C4 \\
\hline PM & $\begin{array}{c}Y=1 \times 10^{-5} r^{2}-0.004 r+6.07 \\
R^{2}=0.9955\end{array}$ & $\begin{array}{c}Y=2 \times 10^{-6} r^{2}-0.011 r+13.13 \\
R^{2}=0.9887\end{array}$ & $\begin{array}{c}Y=5 \times 10^{-6} r^{2}-0.004 r+4.25 \\
R^{2}=0.9952\end{array}$ & $\begin{array}{c}Y=2 \times 10^{-4} r+0.47 \\
R^{2}=0.6770\end{array}$ \\
\hline $\mathrm{CO}$ & $\begin{array}{c}Y=1 \times 10^{-6} r^{2}-0.003 r+3.71 \\
R^{2}=0.6768\end{array}$ & $\begin{array}{c}Y=2 \times 10^{-5} r^{2}-0.082 r+85.45 \\
R^{2}=0.9650\end{array}$ & $\begin{array}{c}Y=2 \times 10^{-6} r^{2}-0.006 r+5.71 \\
R^{2}=0.6688\end{array}$ & $\begin{array}{c}Y=0.00012 r+0.11 \\
R^{2}=0.7204\end{array}$ \\
\hline $\mathrm{NO}_{\mathrm{x}}$ & $\begin{array}{c}Y=-1 \times 10^{-6} r^{2}-0.005 r+18.21 \\
R^{2}=0.9905\end{array}$ & $\begin{array}{c}Y=-9 \times 10^{-6} r^{2}+0.023 r-5.04 \\
R^{2}=0.9974\end{array}$ & $\begin{array}{c}Y=-2 \times 10^{-6} r^{2}-0.006 r+25.49 \\
R^{2}=0.9977\end{array}$ & $\begin{array}{c}Y=2 \times 10^{-6} r^{2}-0.02 r+32.02 \\
R^{2}=0.9991\end{array}$ \\
\hline $\mathrm{O}_{2}$ & $\begin{array}{c}Y=8 \times 10^{-6} r^{2}-0.02 r+23.00 \\
R^{2}=0.8908\end{array}$ & $Y=11 \times 10^{-6} r^{2}-0.03 r+25.75$ & $Y=1 \times 10^{-6} r^{2}+0.004 r+1.15$ & $Y=0.005 r+1.97$ \\
\hline $\mathrm{HC}$ & $\begin{array}{c}1 \times 10^{-7} r^{2}-3 \times 10^{-5} r+0.07 \\
R^{2}=0.5618\end{array}$ & $\begin{array}{c}Y=1 \times 10^{-7} r^{2}-0.0002 r+0.30 \\
R^{2}=0.9175\end{array}$ & $\begin{array}{c}Y=1 \times 10^{-7} r^{2}-9 \times 10^{-5} r+0.12 \\
R^{2}=0.9891\end{array}$ & $\begin{array}{c}Y=1 \times 10^{-7} r^{2}-4 \times 10^{-5} r+0.06 \\
R^{2}=0.9803\end{array}$ \\
\hline
\end{tabular}

$r=$ Engine speed (rpm).

a)

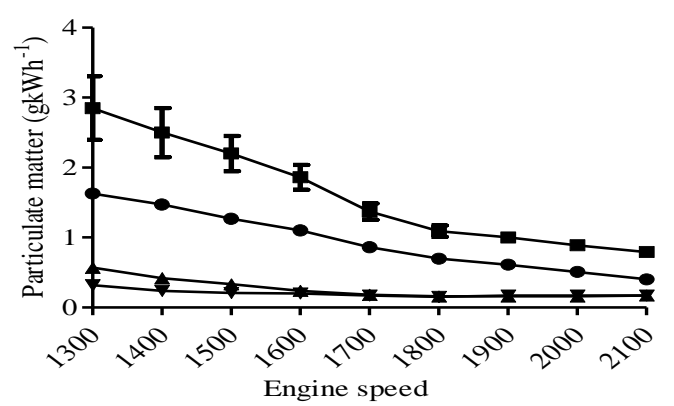

c)

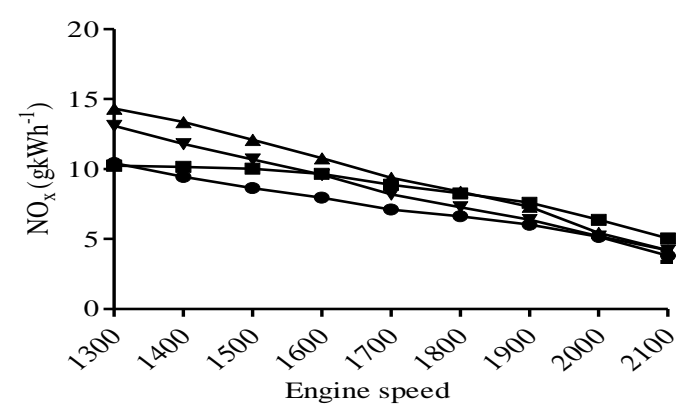

e)

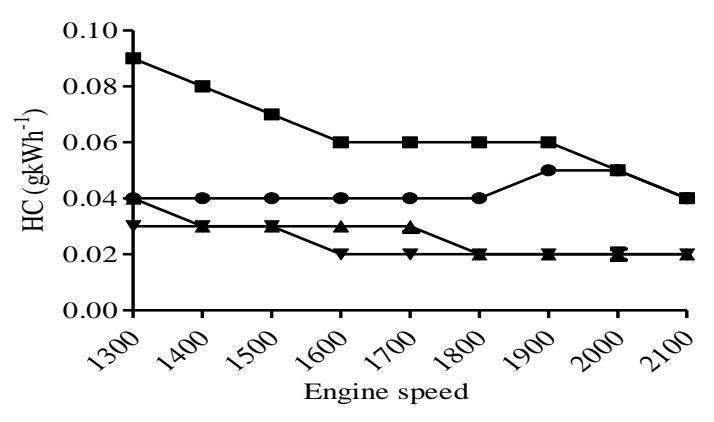

b)

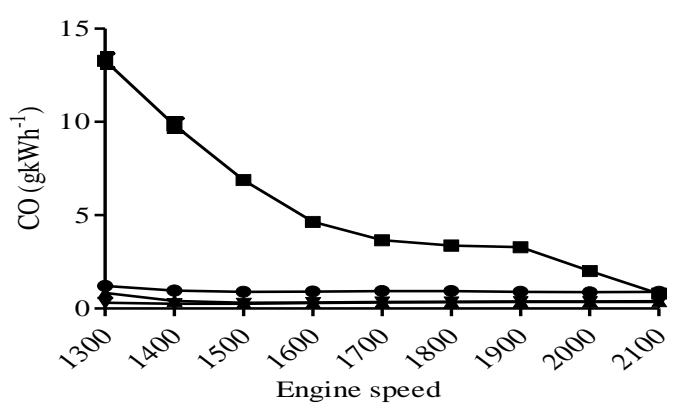

d)

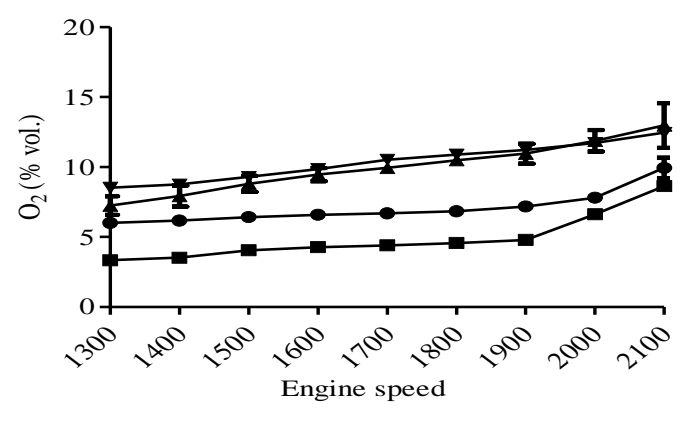

f)

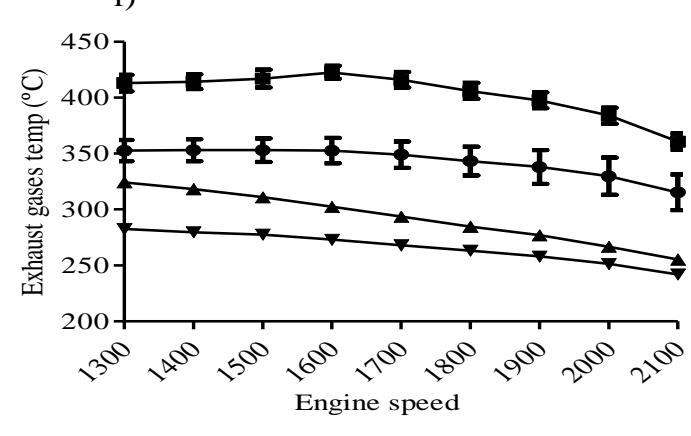

$\because \mathrm{C}_{1} \rightarrow \mathrm{C}_{2} \rightarrow \mathrm{C}_{3} \rightarrow \mathrm{C} 4$

Figure 2 - Variation of exhaust emissions: a) particulate matter; b) carbon monoxide (CO); c) nitrogen oxides $\left(\mathrm{NO}_{\mathrm{x}}\right)$; d) oxygen $\left(\mathrm{O}_{2}\right)$; e) hydrocarbons $(\mathrm{HC})$ and f) exhaust gases temperature, as a function of the engine speed, for Aspirated (C1), Aspirated + Service (C2), Turbocharged + Service (C3) and Turbocharged (C4) settings. 
The engine speed of $1,300 \mathrm{rpm}$ accounts for the highest particulate matter values. At this speed, C2 differed from the value obtained with $\mathrm{C} 1$ (Table 3). Particulate matter tends to decrease as the engine speed increases (Figure 2a). This is due to the higher amount of $\mathrm{O}_{2}$ admitted by the engine at high speeds (Figure 2d), since particulate matter is a residue of the air-fuel mixture combustion.

Table 3 - Engine exhaust emissions (particulate matter; carbon monoxide; nitrogen oxide; oxygen and hydrocarbons) in different speeds for Aspirated (C1), Aspirated + Service (C2), Turbocharged + Service (C3) and Turbocharged (C4) settings.

\begin{tabular}{|c|c|c|c|c|c|c|c|c|c|c|}
\hline \multirow{2}{*}{$\begin{array}{l}\text { Configura- } \\
\text { tion }\end{array}$} & \multicolumn{10}{|c|}{ Particulate matter $\left(\mathrm{g} \mathrm{kWh}^{-1}\right)^{*}$} \\
\hline & 1,300 & 1,400 & 1,500 & 1,600 & 1,700 & 1,800 & 1,900 & 2,000 & 2,100 & Average \\
\hline C1 & 1.63 & 1.47 & 1.27 & 1.10 & 0.86 & 0.70 & 0.62 & 0.51 & 0.40 & $0.95^{b}$ \\
\hline $\mathrm{C} 2$ & 2.85 & 2.50 & 2.20 & 1.86 & 1.37 & 1.09 & 1.00 & 0.89 & 0.79 & $1.62^{\mathrm{a}}$ \\
\hline C3 & 0.57 & 0.42 & 0.33 & 0.24 & 0.18 & 0.16 & 0.16 & 0.16 & 0.17 & $0.26^{\mathrm{c}}$ \\
\hline C4 & 0.32 & 0.24 & 0.21 & 0.19 & 0.17 & 0.15 & 0.17 & 0.17 & 0.17 & $0.20^{\mathrm{c}}$ \\
\hline \multicolumn{11}{|c|}{ Carbon monoxide $\left(\mathrm{g} \mathrm{kWh}^{-1}\right)$} \\
\hline C1 & 1.21 & 0.96 & 0.89 & 0.91 & 0.93 & 0.93 & 0.90 & 0.87 & 0.90 & $0.94^{b}$ \\
\hline C2 & 13.28 & 9.83 & 6.88 & 4.64 & 3.66 & 3.37 & 3.28 & 2.01 & 0.80 & $5.30^{\mathrm{a}}$ \\
\hline C3 & 0.83 & 0.41 & 0.31 & 0.32 & 0.34 & 0.36 & 0.37 & 0.38 & 0.39 & $0.41^{\mathrm{c}}$ \\
\hline C4 & 0.30 & 0.24 & 0.27 & 0.29 & 0.32 & 0.33 & 0.34 & 0.34 & 0.35 & $0.31^{d}$ \\
\hline \multicolumn{11}{|c|}{ Nitrogen oxide (g kWh-1) } \\
\hline C1 & 10.42 & 9.46 & 8.64 & 7.95 & 7.11 & 6.63 & 6.02 & 5.15 & 3.81 & $7.24^{\mathrm{c}}$ \\
\hline $\mathrm{C} 2$ & 10.23 & 10.16 & 10.03 & 9.66 & 8.88 & 8.26 & 7.59 & 6.37 & 5.04 & $8.47^{b}$ \\
\hline C3 & 14.32 & 13.36 & 12.10 & 10.76 & 9.37 & 8.37 & 7.31 & 5.44 & 4.19 & $9.47^{a}$ \\
\hline C4 & 13.09 & 11.79 & 10.70 & 9.59 & 8.20 & 7.28 & 6.38 & 5.20 & 4.19 & $8.49^{b}$ \\
\hline \multicolumn{11}{|c|}{ Oxygen (\%vol.) } \\
\hline C1 & 6.00 & 6.18 & 6.43 & 6.59 & 6.70 & 6.84 & 7.19 & 7.81 & 9.93 & $7.07^{c}$ \\
\hline $\mathrm{C} 2$ & 3.56 & 3.52 & 4.05 & 4.28 & 4.40 & 4.57 & 4.79 & 6.62 & 8.65 & $4.91^{d}$ \\
\hline C3 & 7.24 & 7.93 & 8.80 & 9.47 & 9.95 & 10.50 & 10.96 & 11.87 & 12.98 & $9.97^{b}$ \\
\hline C4 & 8.52 & 8.75 & 9.29 & 9.86 & 10.53 & 10.90 & 11.23 & 11.73 & 12.46 & $10.36^{a}$ \\
\hline \multicolumn{11}{|c|}{ Hydrocarbons $\left(\mathrm{g} \mathrm{kWh}^{-1}\right)$} \\
\hline C1 & 0.05 & 0.04 & 0.04 & 0.04 & 0.04 & 0.04 & 0.05 & 0.05 & 0.04 & $0.04^{b}$ \\
\hline $\mathrm{C} 2$ & 0.09 & 0.08 & 0.07 & 0.06 & 0.06 & 0.06 & 0.06 & 0.05 & 0.04 & $0.06^{a}$ \\
\hline C3 & 0.04 & 0.03 & 0.03 & 0.03 & 0.03 & 0.02 & 0.02 & 0.02 & 0.02 & $0.03^{c}$ \\
\hline C4 & 0.03 & 0.03 & 0.03 & 0.02 & 0.02 & 0.02 & 0.02 & 0.02 & 0.02 & $0.02^{d}$ \\
\hline
\end{tabular}

*Means followed by the same letter in the column do not differ $(p \leq 0.05)$ between each other by Tukey test.

Braun et al. (2003) state that particulate matter forms in oxygen-poor atmospheres through pyrolysis. In this sense, one can affirm that air supercharging (C3 and C4) increases oxygen availability for combustion, since these tests reduced particulate matter emissions by $72.63 \%$ and $78.95 \%$, respectively, in relation to $\mathrm{C} 1$. The reduction of PM using turbocharged can be explained by the increase of $\mathrm{O}_{2}$ (Figure $2 \mathrm{~d}$ ), reducing the possibility of rich mixture formation in the engine combustion chamber (Estrada et al., 2016).
Figure $2 \mathrm{~b}$ shows that the $\mathrm{C} 2$ configuration stands out for high $\mathrm{CO}$ emission. This configuration emits $463.83 \%$ more $\mathrm{CO}$ than the original engine configuration (Table 4). Rich mixtures increase the concentration of this pollutant, due to lack of homogeneity of the mixture. In other words, according to Sayin (2010), this is because $\mathrm{CO}$ is produced by burning under conditions of low oxygen (incomplete combustion) and/or high temperature (Figure 2f).

Table 4 - Mean values of the engine exhaust emissions variables and its variation $(\Delta)$ regarding configuration $C 1$ (aspirated engine).

\begin{tabular}{ccrcrcrrrrr}
\hline Conf. & $\begin{array}{c}\mathrm{PM} \\
\left(\mathrm{g} \mathrm{kWh}^{-1}\right)\end{array}$ & $\Delta(\%)$ & $\begin{array}{c}\mathrm{CO} \\
\left(\mathrm{g} \mathrm{kWh}^{-1}\right)\end{array}$ & $\Delta(\%)$ & $\begin{array}{c}\mathrm{NO}_{\mathrm{x}} \\
\left(\mathrm{g} \mathrm{kWh}^{-1}\right)\end{array}$ & $\Delta(\%)$ & $\begin{array}{c}\mathrm{O}_{2} \\
(\% \mathrm{vol} .)\end{array}$ & $\Delta(\%)$ & $\begin{array}{c}\mathrm{HC} \\
\left(\mathrm{g} \mathrm{kWh}^{-1}\right)\end{array}$ & $\Delta(\%)$ \\
\hline $\mathrm{C} 1$ & $0.95^{\mathrm{b}}$ & 0.00 & $0.94^{\mathrm{b}}$ & 0.00 & $7.24^{\mathrm{c}}$ & 0.00 & $7.07^{\mathrm{c}}$ & 0.00 & $2.13^{\mathrm{d}}$ & 0.00 \\
$\mathrm{C} 2$ & $1.62^{\mathrm{a}}$ & 70.53 & $5.30^{\mathrm{a}}$ & 463.83 & $8.47^{\mathrm{b}}$ & 16.99 & $4.91^{\mathrm{d}}$ & -30.55 & $2.51^{\mathrm{b}}$ & 17.84 \\
$\mathrm{C} 3$ & $0.26^{\mathrm{c}}$ & -72.63 & $0.41^{\mathrm{c}}$ & -56.38 & $9.47^{\mathrm{a}}$ & 30.80 & $9.97^{\mathrm{b}}$ & 41.02 & $2.71^{\mathrm{a}}$ & 27.23 \\
$\mathrm{C} 4$ & $0.20^{\mathrm{c}}$ & -78.95 & $0.31^{\mathrm{d}}$ & -67.02 & $8.49^{\mathrm{b}}$ & 17.27 & $10.36^{\mathrm{a}}$ & 46.53 & $2.42^{\mathrm{c}}$ & 13.62 \\
\hline
\end{tabular}

*Means followed by the same letter in the column do not differ $(p \leq 0.05)$ between each other by Tukey test. ${ }^{* *}$ Particulate matter (PM); carbon monoxide (CO); nitrogen oxide $\left(\mathrm{NO}_{\mathrm{x}}\right)$; oxygen $\left(\mathrm{O}_{2}\right)$; hydrocarbons $(\mathrm{HC})$. 
When analyzing the $\mathrm{CO}$ variable as a function of the speed for all engine configurations (Table 3), only at $1,300 \mathrm{rpm}$ the results differ significantly in the four groups. Corroborating the results obtained in this study, Valente et al. (2012) observed that CO emissions decrease the lower the load applied to the engine. Brunetti (2012) warns of the risks caused by this pollutant, since it reacts with hemoglobin reducing the ability of the blood to carry $\mathrm{O}_{2}$.

When operating at 2,100 rpm (Figure 2c), in relation to $1,300 \mathrm{rpm}$, i.e., when the engine loads decrease, there is an average reduction of $64.14 \%$ in $\mathrm{NO}_{x}$ emission, for all configurations evaluated. The addition of turbocharger (configurations $\mathrm{C} 3$ and $\mathrm{C} 4$ ) increased $\mathrm{NO}_{x}$ emission when compared to the configuration C1, with the lowest emission (Table 4). This is because of the greater availability of oxygen, provided by the supercharging of air.

According to Carvalho Júnior \& Lacava (2003), $\mathrm{NO}_{x}$ formation is related to the high temperatures in the combustion chamber. With the addition of turbocharger + service in the injection pump (configuration C3), greater heat generation is expected due to the increased amount of oxidizer and fuel. This situation can be confirmed based on the analysis of Figure 2c, with the highest levels of $\mathrm{NO}_{x}$ emission. Furthermore, these emissions are proportional to the load applied to the engine.

Figure $2 \mathrm{~d}$ shows that the $\mathrm{O}_{2}$ emitted by the engine increased as the speed was higher, for all the studied configurations, especially for the configurations with turbocharger (C3 and C4). The greater the volume of air admitted, the easier it is to achieve the total combustion of the fuel load (Giacosa, 1980). According to Brunetti (2012), the improvement of the combustion process reduces smoke, $\mathrm{CO}$ and $\mathrm{HC}$, but increases $\mathrm{NO}$ levels.

Lima et al. (2007) state that $\mathrm{O}_{2}$ exhaust emission levels are good parameters for the assessment of combustion efficiency. In cases of low levels of $\mathrm{O}_{2}$ emissions, the consensus is that the mixture is formed with excess fuel, i.e., rich mixture. This can be seen in Figure 2d, for engine configuration $\mathrm{C} 2$. In the case of air/fuel mixtures with excess oxidizer (poor mixture), there are higher $\mathrm{O}_{2}$ emissions, as observed for configuration C4 (Figure 2d).

Figure $2 \mathrm{e}$ shows the behavior of $\mathrm{HC}$ emissions. As for $\mathrm{CO}$, the condition of $10 \%$ increase in injected fuel (C2) stands out for high $\mathrm{HC}$ emissions. Hydrocarbons are formed by the partial decomposition of fuel during combustion and may occur in regions of the chamber where the mixture is excessively rich or poor (Agarwal et al., 2011; Brunetti, 2012). Even with a stoichiometric mixture, the concentration of this pollutant is high, due to lack of homogeneity of the mixture.

Regardless of the engine configuration, $\mathrm{HC}$ emissions varied from $0.03 \mathrm{~g} \mathrm{kWh}^{-1}$, at the highest engine speed $(2,100 \mathrm{rpm})$, to $0.05 \mathrm{~g} \mathrm{kWh}^{-1}$, on average, at 1,300 rpm (Table 3). This represents a $40 \%$ reduction. At higher speed (above 1,900 rpm), $\mathrm{O}_{2}$ is available in sufficient quantity (Figure 2d); however, at low speeds, with high loads imposed on the engine, $\mathrm{O}_{2}$ drastically reduces. Thus, hydrocarbons emission is lower at low loads compared with the engine running at full load.

Figure $2 f$ shows the behavior of the exhaust gas temperature as a function of engine speed. The maximum gas temperatures measured for configurations $\mathrm{C} 1, \mathrm{C} 2$, C3 and C4 were 353.00; 422.67; 324.33; and $282.67^{\circ} \mathrm{C}$, respectively. The lower temperatures occurred for the engine configurations with turbocharger (C3 and C4). Moreover, higher gas temperatures are related to the enrichment of the air/fuel mixture, as verified in configuration $\mathrm{C} 2$.

\section{Conclusions}

Emissions of particulate matter and $\mathrm{CO}$ reduced when turbocharger was used alone compared to the original configuration (aspirated).

Engine fuel supercharging, compared to the original configuration, significantly increases the emissions of particulate matter, $\mathrm{CO}, \mathrm{NO}_{\mathrm{x}}$ and $\mathrm{HC}$.

Emissions of pollutants from the diesel-cycle engine decrease with the reduction of the load applied to the engine.

\section{References}

Agarwal D, Singh SK, Agarwal AK (2011) Effect of Exhaust Gas Recirculation (EGR) on performance, emissions, deposits and durability of a constant speed compression ignition engine. Applied Energy 88(8):2900-2907.

Amoroso A, Beine HJ, Sparapani R, Nardino M, Allegrini I (2006) Observation of coinciding arctic boundary layer ozone depletion and snow surface emissions of nitrous acid. Atmospheric Environment 40(11):1949-1956.

Braun S, Appel LG, Schmal M (2003) A poluição gerada por máquinas de combustão interna movidas a Diesel - A questão dos particulados. Estratégias atuais para a redução e controle das emissões e tendências futuras. Química Nova 27(3):472-482.

Bilski B (2013) Exposure to audible and infrasonic noise by modern agricultural tractors operators. Applied Ergonomics 44(2):210-214.

Brunetti F (2012) Motores de combustão interna - V. 2. Blucher. 485p.

Carvalho Júnior JAC, Lacava PT (2003) Emissões em processos de combustão. UNESP. 139p.

Estrada JS, Schlosser JF, Farias MS, Barbieri JP, Rüdell IIP, Damasceno J (2016) Emissões de gases poluentes de um motor ciclo Diesel utilizando misturas de biocombustíveis. Revista Agrarian 9(33):274-279. 
Farias MS (2014) Avaliação de motores de tratores agrícolas utilizando dinamômetro móvel. UFSM (Dissertação de Mestrado em Engenharia Agrícola).

Frantz UG, Schlosser JF, Farias MS, Ferigolo LF, Ebert LC (2014) Eficiência energética de um trator agrícola utilizando duas configurações de tomada de potência. Ciência Rural 44(7):1219-1222.

Giacosa D (1980) Motores endotérmicos - 3aㅡ Ed. Dossat. 752p.

Giakoumis EG, Rakopoulos CD, Dimaratos AM, Rakopoulos DC (2013) Exhaust emissions with ethanol or n-butanol Diesel fuel blends during transient operation: A review. Renewable and Sustainable Energy Reviews 17:170-190.

Hosseinpoor AR, Forouzanfar MH, Yunesian $M$, Asghari F, Naieni KH, Farhood D (2005) Air pollution and hospitalization due to angina pectoris in Tehran, Iran: A time-series study. Environmental Research 99(1):126-131.

Janulevicius A, Juostas A, Pupinis G (2013) Tractor's engine performance and emissions characteristics in the process of ploughing. Energy Conversion and Management 75:498-508.

Karabektas M (2009) The effects of turbocharger on the performance and exhaust emissions of a diesel engine fuelled with biodiesel. Renewable Energy 34(4):989-993.

Lebedevas S, Makareviciene V, Sendzikiene E, Zaglinskis J (2013) Oxidation stability of biofuel containing Camelina sativa oil methyl esters and its impact on energy and environmental indicators of diesel engine. Energy Conversion Management 65:33-40.
Lima LC, Macedo ARM, Macedo ARL, Marques E (2007) Construção e avaliação de um monitor de combustão industrial. Revista Tecnologia 28(1):77-84.

Márquez L (2012) Tractores Agrícolas: Tecnología y Utilización. B\&H Grupo Editorial. 844p.

Perin GF, Schlosser JF, Farias MS, Estrada JS, Treichel H, Galon L (2015) Emissões de motor agrícola com o uso de diferentes tipos de diesel e concentrações de biodiesel na mistura combustível. Pesquisa Agropecuária Brasileira 50(12):1168-1176.

Pilusa TJ, Mollagee MM, Muzenda E (2012) Reduction of Vehicle Exhaust Emissions from Diesel Engines Using the Whale Concept Filter. Aerosol and Air Quality Research 12(5):994-1006.

Sayin C (2010) Engine performance and exhaust gas emissions of methanol and ethanol-Diesel blends. Fuel 89(11):3410-3415.

Tadano YS, Borillo GC, Godoi AFL, Cichon A, Silva TOB, Valebona FB, Errera MR, Neto RAP, Rempel D, Martin L, Yamamoto Cl, Godoi RHM (2014) Gaseous emissions from a heavy-duty engine equipped with SCR after treatment system and fuelled with Diesel and biodiesel: Assessment of pollutant dispersion and health risk. Science of The Total Environment 500-501(1):64-71.

Valente OS, Pasa VMD, Belchior CRP, Sodré JR (2012) Exhaust emissions from a diesel power generator fuelled by waste cooking oil biodiesel. Science of The Total Environment 431(1):57-61. 